\title{
Post-Critique, Politics, and the Political in Educational Philosophy
}

\author{
Naomi Hodgson (Liverpool Hope University)
}

\begin{abstract}
:
The recent Manifesto for a Post-Critical Pedagogy introduced a specifically pedagogical register into theoretical and methodological consideration of post-critique. Focusing on a specific aspect of the Manifesto - the view that the political concerns of much critical educational research position education as instrumental to politics to the extent that the "educational" in educational research is left out of the picture - I ask to what extent we can defend the view that education and politics should be separate in our enquiries? Drawing on a particular account of the separation of education and politics I suggest that what is at issue is not the political as such but the particular, sociological, register of politics at work in critical educational research. To bracket out the political is potentially to leave everyday flesh and blood experiences of education out of the picture.
\end{abstract}

Keywords:

affirmative; essence; political; post-critique; surface

The notion of the post-critical has gained traction in a number of fields in recent years, from literary studies to social sciences to philosophy, in work that has questioned the epistemological and ontological force of critique. In literary studies, for example, Frank and Sedgwick (1995), Anker and Felski (2017) and others have sought to move away from the "hermeneutics of suspicion" that has characterised critical textual analysis. In the field of social sciences, Latour $(2004,2005)$ has questioned the ability of critique to gather publics, and what its current form means for the relationship between science and democracy. While in both cases we see a shift away from a particular form of political reading, politics remains part of the picture, of what we are addressing, why, and how, as academics.

The post-critical has been given more recent articulation in the field of education in the Manifesto for $a$ Post-Critical Pedagogy (Hodgson et al., 2017), which sought to make manifest a more general sense in the field of educational philosophy of a need to move beyond the political emphasis of much critical educational research. Influenced by Latour, Arendt, and more literary influences on the field such as Cavell and Emerson, the Manifesto sets out five principles for a post-critical attitude to educational inquiry that seeks "not to debunk but to protect and to care”. Echoing work in literary studies, we proposed a shift from the hermeneutical pedagogy that we associate with critical pedagogy, to pedagogical hermeneutics, based on "the assumption that we can speak and act - together" (Hodgson et al., 2017, p. 18):

It is precisely the challenges of living together in a common world that constitute the hope that make education continue to seem a worthwhile activity. Hermeneutics isn't a (unsolvable) problem, but rather something educators need to create. We shouldn't speak and act on the basis of a priori assumptions about the (im)possibility of real mutual understanding and respect, but rather show that, in spite of the many differences that divide us, there is a space of commonality that only comes about a posteriori (cf. Arendt, Badiou, Cavell). (Hodgson et al., 2017, p. 18)

By invoking hope in the present, we sought to articulate an affirmative mode of educational inquiry, focused not (or not only) on critique of the dysfunction of our institutions but on reclaiming "the suppressed parts of our experience" (Hodgson et al., 2017, p. 19; I will return to what is implied by "suppressed" here later). The invocation of an Arendtian love for the world meant

not an acceptance of how things are, but an affirmation of the value of what we do in the present and thus of things that we value as worth passing on. But not as they are: educational hope is about the possibility of a renewal of our common world. (Hodgson et al., 2017, p. 18)

In this essay I focus on a specific aspect of the Manifesto - the view that the political concerns of much critical educational research position education as instrumental to politics to the extent that the "educational" in educational research is left out of the picture - to ask: Even if we accept that critical accounts, which seek to release education from its fulfilment of economic policy or reproduction of inequality, only reconceive it in terms of 
other political aims, to what extent can we defend the view that education and politics should be separate in our enquiries?

This has been a year distinguished in its awfulness: environmental disasters including wildfires and floods, the killing of black citizens by police in the US, and a pandemic that has brought existing inequalities and prejudices into sharp relief. School strikes, the Black Lives Matter movement, providing education to children and young people both at home and at school, reopening amid ongoing social distancing and enhanced health and safety measures, and caring for those struggling, grieving, and anxious when returning to formal education: educational institutions and professionals have had no choice but to respond and adapt to each cause and crisis. Discussion of education today, then, whether public or academic, seems unavoidably political. So, what form do recent interventions that argue, following Arendt, that the defence of education requires strict separation of politics and education (where education usually refers to schooling) take and what affirmative force do they have?

The notion of the school as separate from politics is a radical move: from a critical theoretical perspective, the school is political all the way down, from the content of the curriculum, the diversity of the teaching staff, the pedagogies, policies, and aims; from the perspective of those designing policy, there are wider socioeconomic aims to which schools must contribute; for those implementing policy on a local level, their success is measured on their ability to foster an inclusive learning environment and to 'close the gap' between those from disadvantaged backgrounds and the highest achieving, and so on. But this separation is a position that guides those in power themselves: the notion of equal opportunities relies on the idea that where you are born should not determine educational outcomes and therefore all children should receive the same standard of access to education. The differences in outcomes can then be attributed to individual school failings, or to individuals' lack of aspiration, grit, and resilience. We should be careful, then - particularly at this time when certain aspects of public discourse are prone to write off any appeal to identity categories as 'woke', 'political correctness' or 'left-wing bias' - how we define and articulate the political as it relates to education. Given the year that 2020 has been and the longer term challenges we face, it seems counter-intuitive perhaps to insist on the separation of education and politics. How education is governed, who it excludes, how it prepares our children for the future, and so on are pressing concerns, as any newspaper or indeed academic call for papers published since March 2020 will attest.

The argument for education and politics as appropriately separate spheres is strongly articulated by Joris Vlieghe and Piotr Zamojski. The ontological turn in their work effects the affirmative attitude called for by post-critical pedagogy by focusing in on the essence of education. In their 2019 book Towards an Ontology of Teaching: Thing-centred Pedagogy, Affirmation and Love for the World, Vlieghe and Zamojski investigate what "teaching consists [of] essentially" (p. 58) and "what education essentially is” (p. 73). In a 2020 article, they set out their position in relation to the 'critical' position that is concerned with recognising the inevitable political dimension of education. As they characterise it: either it needs to be revealed to those who don't realise its political function or, once it has been revealed, education needs to work in service of emancipation from this status quo. For Vlieghe and Zamojski, the distinction between education and politics is not a denial that there is anything political about education, rather it is a reorienting of critique from being predominantly concerned with politics at the expense of the educational. Relentless radical critique is, they argue, self-defeating (Vlieghe \& Zamojski, 2020, p. 3). As Rancière (1991) has argued, "the very idea that we, as educators, first need to enlighten the oppressed other about her oppressive conditions, installs a regime of inequality we can never escape from” (Vlieghe \& Zamojski, 2020, p. 3).

Vlieghe and Zamojski draw on Arendt's (1958, 1961) distinction between education and politics as two separate spheres, and they further distinguish between the two senses of politics she offers: the strong sense and the wrong sense. The former refers to:

the activity of those who leave the private sphere behind, in order to gather on the agora, to speak and discuss, and so to perform deeds through which a new beginning can be introduced to our common world. Politics in the strong sense is therefore a practice of establishing the common (Vlieghe \& Zamojski, 2020, p. 4).

Politics "in the wrong sense", on the other hand, is illustrated in the contemporary politicisation of education, in which education acts a means to realise "a political dream that exploits and sacrifices the newness of the new generation to fulfil the fantasy of the perfect society" (Vlieghe \& Zamojski, 2020, p. 4). The argument for the need to separate education from politics is premised on the Arendtian understanding of education as "a response to newness", which gives "the newcomers the possibility to begin anew with this world” (Vlieghe \& Zamojski, 2020, p. 4). What makes this passing on of the old world to the new generation "properly humane and educational is that this gift should be passed on in such a way that the new generation can actually take up this world in ways we, the adults, did not and could not have foreseen” (Vlieghe \& Zamojski, 2020, p. 4).

Vlieghe and Zamojski restate the idea (see Hodgson et al., 2017, 2018) that critical work is premised on hate: 
On the basis that the world is assumed [by the critic] to be evil, the stance of this master of critique is driven by a certain hate for the existing form of the world, and simultaneously by love for an imaginary world that will never come. (Vlieghe \& Zamojski, 2020, p. 10)

This supports the link between an affirmative approach and an inherently educational one:

We take our cue here, again, from Arendt, who concludes her essay on the crisis in education with the assertion that education essentially consists of displaying love for the world, which suggests (although Arendt proposed an alternative argument when developing the strong sense of politics in her political writings, e.g. Arendt, 1958) that politics is predicated on hate for the world (Vlieghe \& Zamojski, 2020, p. 5).

Vlieghe and Zamojski nuance the idea that politics is driven by hate and education by love in two ways: first, in relation to an ontological conception of love and hate, and second in relation to Agamben's notion of potentiality.

In relation to the first, to conceive of love and hate ontologically they draw on Scheler's (1973) conception of love and hate as "two fundamental modes of world disclosure” (Vlieghe \& Zamojski, 2020, p. 5). Love "is a way of relating to the world that allows the world to open up (and hence to be affirmed as worthwhile), which invites us to explore and study it, and to pass it on to the next generations” (Vlieghe \& Zamojski, 2020, p. 5). Hate

narrows down the world (which is, phenomenologically speaking, a precise description of the manner in which the world appears to a political activist: there is something in the world that is so wrong that one simply needs to correct this wrong rather than putting one's energy into anything else) (Vlieghe \& Zamojski, 2020, p. 5).

The references to "hate” (Hodgson et al., 2017, 2018) and to "evil” in later work by Vlieghe and Zamojski (2020) refer to the reliance of the critical pedagogue on the very unequal status quo from which they seek to emancipate the other and their standing in judgment of it from outside. To be driven by a passion of hate - of injustice, of inequality - seems not inherently bad, however; the point is that "relentless radical critique” (Vlieghe \& Zamojski, 2020, p. 3) risks becoming an almost myopic focus whereby the possibility of education is denied, such is the belief in the evil of the system. Articulated in Arendtian terms:

To formulate more positively the role of the pedagogue as initiating the new generation into a common world, we offer the idea of a post-critical pedagogy, which requires a love for the world. This is not an acceptance of how things are, but an affirmation of the value of what we do in the present and thus of things that we value as worth passing on (Hodgson et al., 2017, p. 18).

In relation to the second way in which they nuance the account, they draw on Agamben's notion of potentiality to situate Arendt's insistence on the autonomy of education:

because study comes with an experience and sense of potentiality, it also makes possible political thought and action. At the risk of making a truly paradoxical statement, one must first experience pure potentiality in the autonomous, separate sphere of education, to be able to intervene in the current order of things in politics. In that sense, education is not just an end in itself, but precisely a pure means: it could be instrumental for politics (which explains why it can be so easily instrumentalised), but it can only be of use on the condition that it remains fully in potentiality and that this political potential does not get actualised (Vlieghe \& Zamojski, 2020, p. 11).

The bracketing out of politics in order that the pedagogical realm is unencumbered by the fantasies of the older generation, however, seems compromised by the tone in which Vlieghe and Zamojski present the binaries of love and hate, the teacher and the activist. Love, in the Arendtian formulation above, is articulated in terms of what we do in our pedagogical relationships that constitute that initiation, and our judgments on and investments in what we value as worth passing on. In expressing a concern with what we value this seems to inherently and unavoidably entail the political. This separation of politics and education in view of essences also seems to imply the bracketing out of subjectivity, as if a subject matter could be taught and learned without our very subjectivity sitting between us and the world.

The argument that politics is seen to detract from, supercede, or determine educational concerns in critical pedagogy and critical educational research more generally as it is made by Vlieghe and Zamojski overlooks that a particular register of politics is at work: a predominantly sociological one that informs much educational research that is ordered around identity categories, such as race and gender, and institutions, e.g. school, university, government. Taking this into account, the relationship between education and politics in the field of educational research makes sense. It is perhaps not 'politics' as such that is the problem but the conception of it that potentially closes down educational aspects. This sociological register of politics as it appears in the critical educational literature is left unquestioned in Vlieghe and Zamojski's article in that they focus not on the conception of the political at work in critical pedagogy but the way it impinges on education.

As suggested earlier, part of the affirmative aspect of the post-critical entails the will to articulate that which is 
left out of the picture, not only by dominant theoretical and methodological approaches but also prevailing discourses. Placing strict conditions on what education and politics are and can be, however, seems to narrow down the picture of both. It is possible to resist the instrumentalist overdetermination of school education (and the account Vlieghe and Zamojski offer does seem limited to school education) without denying the inherent existence of the political in the educational (and vice versa). What does it mean for our work to consider the relationship between the educational and the political more broadly rather than restricting our articulation of new approaches to a binary of school education and a sociological conception of politics? (For one possible answer see Standish, 2019).

The force of Arendt's argument for the separation of education and politics (briefly, that the political concerns of modern education "insofar as it attempts to establish a world of children, destroys the necessary conditions for vital development and growth" (Arendt, 1953, p. 8)) lies in part in its call to test ourselves: to what extent are we taking responsibility as the older generation for present problems? To what extent are we predetermining who we want our children to be? To what extent are my fears for the future rooted in my sense of lack of control of the present? These are not only academic questions. They reflect the very concerns - mundane and existential - we face each day as parents, educators, grown-ups.

A strong impetus of critical educational research is the resistance of forms of governance and subjectivation that entrench or constitute inequity due to discrimination and injustice. The turn to the post-critical seeks to reanimate the possibility of critique in this sense, not through an attitude of suspicion and debunking but of affirming that which we value and of articulating that which is left out of the picture. Concerned that Vlieghe and Zamojski's focus on essences is potentially a totalitarian move, Kai Wortmann goes in "the opposite direction: not reaching down to the deep essences but rather staying on the surface of things" (2019, p. 475). I take Wortmann's approach as a call not to restrict ourselves to the merely superficial, but rather as a concern for the mundane, and with what we can see. This does not imply an analysis that lacks depth, nor one that seeks essences, at least in the sense that Vlieghe and Zamojski invoke. $^{1}$

In the context of discussions of the post-critical, the invocation of surface and depth has a particular resonance. It is precisely such topological accounts of reading, those that offer a suspicious reading that reveals "hidden ideology ... the workings of power” (Moi, 2017, p. 175), that post-critique in literary theory sought to move away from. A similar move is proposed by post-critical pedagogy - towards an attitude that does not seek to debunk but to affirm. But Vlieghe and Zamojski offer a reading that is explicit in its suspicion of politics and that seeks to reveal the essence of education and teaching that has heretofore been concealed by it. Wortmann's appeal to attend to what is on the surface of things invokes a need to attend to our everyday practices and experience, bringing together the affirmative and the critical. In reference to the post-critical work of Latour, Anker and Felski, and Sedgwick, Wortmann notes that the new vocabularies they introduce "find hope not deep down but at the surface of things (Best \& Marcus 2009)” (Wortmann, 2019, p. 476). The idea mentioned earlier of reclaiming "the suppressed parts of our experience” (Hodgson et al., 2017, p. 19) perhaps risks echoing the suspicion that informs critical readings. In an affirmative vein, however, I take it to refer to those aspects of our experience we cannot (yet) articulate, that are left out of the picture by dominant discourses and how they articulate our practices and their purposes, and the need to (re)establish "our relation to our words, opening them to question, and giving philosophical attention to these devalued aspects of our forms of life” (Hodgson et al., 2017, p. 17). By narrowing down education to essences and clipping the political - not politics in the sociological sense, but the political - out of the picture, the affirmative account of education is denied any sense of the tangible. It brackets out that which constitutes the flesh and blood of education.

\section{References}

Agamben, G. (2000). Potentialities. Collected essays in philosophy. (D. Heller-Roazen, Trans.). Stanford University Press.

Anker, E. S., \& Felski, R. (2017). Introduction. In E. S. Anker, \& R. Felski (Eds.), Critique and postcritique (pp. 1-28). Duke University Press.

Arendt, H. (1958). The human condition. University of Chicago Press.

Arendt, H. (1961). The crisis in education. In H. Arendt, Between past and future: Eight exercises in political thought (pp. 173-196). Viking Press.

Best, S., \& Marcus, S. (2009). Surface reading: An introduction. Representations, 108(1), 1-21. https://doi.org/10.1525/rep.2009.108.1.1

Frank, A., \& Sedgwick, E. (1995). Shame in the cybernetic fold: Reading Silvan Tomkins. Critical Inquiry, $21(2), 496-522$.

Hodgson, N., Vlieghe, J., \& Zamojski, P. (2017). Manifesto for a post-critical pedagogy. punctum books. 
Hodgson, N., Vlieghe, J., \& Zamojski, P. (2018). Education and the love for the world: Articulating a post-critical educational philosophy. Foro de Educación, 16(24), 7-20. https://doi.org/10.14516/fde.576

Hodgson, N., \& Ramaekers, S. (2019). Philosophical presentations of raising children: The grammar of upbringing. Palgrave Macmillan. https://doi.org/10.1007/978-3-030-12540-0

Latour, B. (2004). Why has critique run out of steam? From matters of fact to matters of concern. Critical Inquiry, 30(2), 225-248.

Latour, B. (2005). From Realpolitik to Dingpolitik or how to make things public. In B. Latour, \& P. Weibel (Eds.), Making things public: Atmospheres of democracy (pp. 14-43). Center for Art and Media.

Moi, T. (2017). Revolution of the ordinary. University of Chicago Press.

Rancière, J. (1991). The ignorant schoolmaster. (K. Ross, Trans.). Stanford University Press. (Original work published 1987)

Scheler, M. (1973). Formalism in ethics and non-formal ethics of values. A new attempt toward the foundation of an ethical personalism. (M. S. Frings and R. L. Funk, Trans.). Northwestern University Press. (Original work published 1913, 1916)

Sedgwick, E. K. (2003). Paranoid reading and reparative reading, or, you're so paranoid, you probably think this essay is about you. In E. K. Sedgwick, Touching feeling: Affect, pedagogy, performativity (pp. 123-151). Duke University Press.

Standish, P. (2019). The educational is political. Educational Studies in Japan: International Yearbook, 13, 5-22. https://doi.org/10.7571/esjkyoiku.13.5

Vlieghe, J., \& Zamojski. P. (2019). Towards an ontology of teaching. Thing-centred pedagogy, affirmation and love for the world. Springer. https://doi.org/10.1007/978-3-030-16003-6

Vlieghe, J., \& Zamojski, P. (2020). Redefining education and politics: On the paradoxical relation between two separate spheres. Policy Futures in Education, 18(7), 864-877. https://doi.org/10.1177/1478210320943808

Wittgenstein, L. (1953). Philosophical investigations. (G. E. M. Anscombe, Trans.). Basil Blackwell. (Original work published 1953)

Wortmann, K. (2019). Post-critical pedagogy as poetic practice: Combining affirmative and critical vocabularies. Ethics and Education, 14(4), 467-481. https://doi.org/10.1080/17449642.2019.1669942

\section{Recommended Citation}

Hodgson, N. (2020). Post-critique, politics, and the political in educational philosophy. On Education. Journal for Research and Debate, 3(9). https://doi.org/10.17899/on_ed.2020.9.3

\section{About the Author}

Naomi Hodgson is Associate Professor of Education Studies at Liverpool Hope University, UK. Her research focuses on the relationship between education, governance, and subjectivity. Her most recent publications include Manifesto for a PostCritical Pedagogy, with Joris Vlieghe and Piotr Zamojski (Punctum Books, 2018) and Philosophical Presentations of Raising Children: The Grammar of Upbringing, with Stefan Ramaekers (Palgrave, 2019). Currently she is working on a project, with Stefan Ramaekers and Kip Kline (Lewis University, US), titled Upbringing, Agency, and Subjectivity in an Algorithmic Age.

\footnotetext{
${ }^{1}$ An alternative conception is found in Wittgenstein and the idea that "Essence is expressed by grammar" (1953, \#371), that is, in our very usage of words. His grammatical investigations seek “to understand something that is already in plain view” (\#89), rather than a deeper, ultimate meaning. See Hodgson \& Ramaekers (2019) for an articulation of this in relation to the post-critical.
} 